Jakub POTULSKI

Uniwersytet Gdański

\title{
„Rosja wyparta z Europy” - konsekwencje dla porządku międzynarodowego na progu XXI w.
}

ednym z istotnych podmiotów współczesnych stosunków międzynaro-
dowych pozostaje Federacja Rosyjska. Formalnie jest to nowe państwo, które powstało po upadku ZSRR, ale współczesna Federacja Rosyjska jest jednocześnie kontynuatorem wcześniejszych tworów geopolitycznych: Związku Radzieckiego, Rosji carskiej i poprzedzających je państwowości ${ }^{1}$. Rosja, z uwagi na swoją wielkość i potencjał, zawsze stanowiła ważny element środowiska międzynarodowego. W okresie istnienia ZSRR państwo rosyjskie było jednym z dwóch światowych supermocarstw, które decydowały o światowej polityce. W ostatniej dekadzie XX w., w wyniku dezintegracji ZSRR państwowość rosyjska doznała poważanego osłabienia i utraciła swoją dotychczasową pozycję i wiele ze swoich światowych przewag. Niezależnie jednak od faktu, osłabienia pozycji Rosji, ograniczenia jej możliwości działania i głębokiego kryzysu polityczno-gospodarczego pozostała ona znaczącym uczestnikiem stosunków międzynarodowych. Ze względu na swój potencjał ludzki, gospodarczy i militarny współczesna Federacja Rosyjska pomimo przejściowego osłabienia pozostaje ważnym elementem stosunków międzynarodowych w dobie tworzenia się nowego ładu ogólnoświatowego, a wiele z tego co będzie działo się w środowisku międzynarodowym w najbliższym czasie zależy od tego, jak ukształtuje się sytuacja wewnętrzna w Federacji Rosyjskiej i jak ukształtuje się jej stosunek do świata zewnętrznego. Dlatego też ważnym elementem rozważań dotyczących współczesnej Rosji stał się problem rosyjskich dylematów dotyczących jej międzynarodowej roli.

Jednym z najważniejszych elementów, który stał się czynnikiem kształtującym politykę zagraniczną Federacji Rosyjskiej na przełomie

M. Menkiszak, Rosyjskie wizje pozimnowojennego porzqdku międzynarodowego, w: Porzadek międzynarodowy u progu XXI wieku, pod red. R. Kuźniara, Warszawa 2005, s. 275. 
XX i XXI w. stał się rozpad ZSRR co wywołało fundamentalne przemiany zachodzące $\mathrm{w}$ strukturze systemu międzynarodowego, a zwłaszcza rozpad tzw. świata dwubiegunowego. Nowy międzynarodowy ład polityczny stanowił konsekwencję załamania się konfliktu Wschód-Zachód w latach 1989-1990. Dezintegracja ZSRR skutkowała nie tylko fundamentalnymi przekształceniami systemu międzynarodowego, ale także wywołała zasadniczą zmianę geopolitycznego położenia Rosji oraz jej pozycji w strukturze międzynarodowej. W 1991 r. na terytorium ZSRR powstało piętnaście nowych państw, zachodnie granice Rosji skurczyły się do linii wyznaczonej w XVII w., a na Kaukazie i w Azji Środkowej do rubieży z połowy XIX w. Rosja utraciła dominujące znaczenie w Basenach Morza Bałtyckiego i Czarnego. Ok. 30 mln Rosjan nagle znalazło się poza granicami kraju, będąc często narażonymi na szykany i pozbawienie podstawowych praw i będąc równocześnie pozbawieni pomocy z zewnątrz.

Przemiany w środowisku wewnętrznym i zewnętrznym spowodowały, że po rozpadzie Związku Radzieckiego Rosja stanęła przed fundamentalnymi pytaniami o jej zakres terytorialny, żywotne interesy, przynależność kulturową i rolę, jaką powinna odgrywać we współczesnym świecie ${ }^{2}$. Procesy zachodzące we współczesnym świecie wywołały potrzebę wypracowania nowej strategii polityki zagranicznej, rozwiązywania problemów globalnych i regionalnych oraz określenia miejsca i ról odrodzonej Rosji w ładzie międzynarodowym. Rosja stanęła przede wszystkim przed problemem ułożenia stosunków dwustronnych z niepodległymi państwami powstałymi na terytorium byłego ZSRR i określeniu swoich stosunków i swojej roli w proradzieckiej przestrzeni ${ }^{3}$. Niekiedy uznaje się, iż głównym problemem był brak jasnego wyobrażenia o tym, jakie miejsce powinna zajmować nowoczesna Rosja w nowym układzie sił globalnych ${ }^{4}$. Wydaje się jednak, iż w okresie transformacji Rosjanie posiadali ukształtowaną wizję przyszłego miejsca swojego kraju w świecie, wizję, której podporządkowali wiele ze swoich działań. Problemem rosyjskim stała się natomiast konfrontacja wyobrażeń z rzeczywistością i realiami świata postzimnowojennego.

2 M. Nizioł, Dylematy kulturowe międzynarodowej roli Rosji, Lublin 2004, s. 7.

3 Por. J. Erickson, ,, Russia will not be trifled with”: geopolitical fact and fantasies, w: Geopolitics, geography and strategy, Londyn 2003, s. 244.

4 S. Bieleń, Tożsamość międzynarodowa Federacji Rosyjskiej, Warszawa 2006, s. 355 . 
Fundamentalne zmiany, które dokonały się w Rosji na przełomie lat osiemdziesiątych i dziewięćdziesiątych były efektem przemian wewnątrz radzieckich elit politycznych i coraz krytyczniejszej oceny rzeczywistości. Reformatorzy radzieccy, którzy zdecydowali się dokonać trudnego wyboru pomiędzy utrzymaniem dotychczasowego modelu a wymogami modernizacji uważali, iż upadek komunizmu pozwoli Rosji na przekształcenie się w nowoczesne państwo na wzór cywilizacji zachodniej. Dominowało przekonanie, że Rosja jest czy też powinna być częścią „wielkiej Europy” i świata Zachodu, z czym wiązało się nastawienie na modernizację na wzór zachodnioeuropejski oraz szukanie kontaktów z wiodącymi krajami zachodnioeuropejskimi. Łatwość i początkowy brak rezerwy w przyjęciu liberalnych zasad ekonomiczno-politycznych wzorowanych na państwach Zachodu w państwach Europy Środkowo-Wschodniej powodowany był także tradycyjnie prozachodnią orientacją elit, których aspiracją było dołączenie do grona państw „,wysoko rozwiniętych" i realizacji własnych ideałów i ambicji. Koniec lat osiemdziesiątych w Rosji charakteryzował się entuzjastycznymi nastrojami wobec ogólnoludzkich wartości świata zachodniego ${ }^{5}$. W rezultacie pierwsze reformy w przebudowywanych według formuły demokratycznej państwach Europy Środkowej i Wschodniej były swoistym „hołdem” dla ideałów liberalnych i przebiegały w zgodności z warunkami formułowanymi przez globalne instytucje - przede wszystkim przez Międzynarodowy Fundusz Walutowy i Bank Światowy, kształtujące podstawy nowego światowego ładu ekonomicznego ${ }^{6}$. Uznaje się niekiedy, że pierwsze reformy społeczne, polityczne i gospodarcze przeprowadzone w Rosji na początku lat dziewięćdziesiątych skierowane były na integrację Rosji ze strukturami europejskimi. Era Gorbaczowa jako przywódcy Rosji stanowiła swoista rewolucję $\mathrm{w}$ rosyjskiej polityce zagranicznej ${ }^{7}$.

Po rozpadzie ZSRR perspektywy rozwoju Rosji wydawały się nowym elitom politycznym, wykorzystującym liberalne i demokratyczne hasła dla legitymizacji swoich działań, przesądzone - postępująca integracja do systemu wysoko rozwiniętych państw Zachodu, odrzucenie rosyjskiego

5 Por. A. Sołżenicyn, Rosja w zapaści, Warszawa 1999, s. 21.

6 J. Gierus, Globalizacja i państwo narodowe, w: Państwo w transformacji w perspektywie XXI w., pod red. W. Materskiego, Warszawa 2000, s. 33.

K. Kik, Interesy narodowe Polski i Rosji w procesach integracji Europy, w: Niemcy, Polska, Rosja, pod red. M. Dobroczyńskiego, Warszawa 1996, s. 143; S. White, Russia's new politics, Cambridge 2000, s. 215-220. 
mesjanizmu. Nowe rosyjskie władze były przekonane, że Zachód będzie wspierała rosyjskie reformy i będzie postrzegał Rosję jako wielkie mocarstwo i równoprawnego partnera. Zgodnie z „duchem" lat osiemdziesiątych i ideą „wspólnego europejskiego domu” Rosja, która odrzuciła system totalitarny, rozpoczęła budowę państwa na wzorach zachodnioeuropejskich demokracji. W zamierzeniach miała to być w sferze materialnej - gospodarka rynkowa, w sferze ustroju - państwo demokratyczne, w sferze wartości-zachodnia wolność i podmiotowość jednostki ${ }^{8}$. Kiedy 1 lutego 1992 r. w Camp David prezydenci Federacji Rosyjskiej i USA stwierdzili, że Rosja i USA nie uważają się wzajemnie za potencjalnych wrogów, a stosunki między obydwoma krajami będą oparte na przyjaźni i partnerstwie, a także wspólnym oddaniu demokracji i wolności obywatelskiej wydawało się, że po zakończeniu zimnej wojny świat jest bardzo bliski urzeczywistnienia prorokowanego przez Francisa Fukyamę „końca historii”. Prozachodnia orientacja elit i społeczeństwa rosyjskiego spowodowała po pierwsze, iż ZSRR a następnie Federacja Rosyjska poczyniły szereg jednostronnych ustępstw w środowisku międzynarodowym na rzecz krajów Zachodu, a po drugie, w kraju o wielowiekowych tradycjach autorytarnych, prowadziła do upowszechnienia się, coraz większej znajomości i akceptacji w świadomości społecznej, wartości cywilizacyjnych świata zachodniego ( $\mathrm{w}$ tym, m.in. uznanie znaczenia praw i wolności obywatelskich oraz budowy społeczeństwa obywatelskiego dla rozwoju kraju).

Ówczesna polityka zagraniczna rosyjska zdominowana była przez tzw. atlantystów, którzy uważali, iż należy Rosję związać z Zachodem w roli równoprawnego partnera i sojusznika oraz dopasować wzory modernizacyjne pochodzące z Europy Zachodniej do warunków panujących w Rosji ${ }^{9}$. Sedno koncepcji proeuropejskiej zawierało się w tzw. „doktrynie Kozyriewa" ${ }^{10} \mathrm{i}$ dążeniu aby w ramach demokratyzacji, deideologizacji

8 E. Zieliński, Współczesna Rosja. Studium polityczno-ustrojowe, Warszawa 1995, s. 15 .

9 J. J. Bogatyriewa, Rosja-Europa: problemy i perspektywy współdziałania, w: Historia i geopolityka. Rosja na progu XXI stulecia, pod red. S. Filipowicza, Warszawa 2000 , s. 85.

${ }^{10} \mathrm{~W}$ swoich koncepcjach dotyczących strategii polityki zagranicznej Rosji ówczesny minister spraw zagranicznych Andriej Kozyriew konsekwentnie opowiadał się za, współpracą z politycznymi i wojskowymi instytucjami państw Zachodu. W swoich poglądach był bardzo konsekwentny, w okresie kiedy kierował Ministerstwem Spraw Zagranicznych doprowadził do przystąpienia Federacji Rosyjskiej do inicjatywy Part- 
i demilitaryzacji przekształcić Rosję w kraj z rozwiniętą gospodarką rynkową, stabilnym systemem społeczno-politycznym, będący równoprawnym partnerem dla krajów Zachodu. Współcześni okcydentaliści, podobnie jak i ich dziewiętnastowieczni poprzednicy, byli przekonani, że realizacja takiego celu jest niemożliwa bez nawiązania partnerstwa i współpracy z krajami zachodnioeuropejskimi, gdyż bez ich pomocy i bez naśladowania modelu europejskiego niemożliwa jest modernizacja kraju, dlatego też opowiadali się za integracją Rosji z zachodnimi strukturami gospodarczymi, politycznymi i wojskowymi (NATO, MFW, ODCE, GATT, UE) ${ }^{11}$. Podkreślali oni, iż Rosja historycznie przynależy do cywilizacji chrześcijańskiej, a więc jest częścią świata europejskiego. Dlatego strategicznym celem Rosji powinno być zbudowanie strategicznego partnerstwa z Zachodem, wstąpienie do struktur Zachodu, gdyż pociągnie to za sobą międzynarodowe wsparcie dla rosyjskich reform i włączenie Rosji do dominującej w świecie grupy wysoko rozwiniętych państw, które odgrywają decydującą rolę w stosunkach międzynarodowych ${ }^{12}$. Rosjanie mieli nadzieję, że po rozpadzie ZSRR i odrzuceniu balastu w postaci nieakceptowanej przez zachodnie społeczeństwa ideologii komunistycznej, wraz z pozostałymi społecznościami Europy Środkowo-Wschodniej będą uczestniczyć w procesie tworzenia Wielkiej Europy, która zgodnie z oczekiwaniami pierwszych rosyjskich reformatorów (Michaił Gorbaczow i Eduard Szewardnadze) miała rozciagać się „od Atlantyku po Ural”. W początkowym okresie przemian rosyjskich wyraźnie dominowała chęć „okcydetalizacji” Rosji, co znalazło swój wyraz m.in. w gorbaczowowskiej koncepcji „wspólnego europejskiego domu”, a także w „doktrynie Kozyriewa", która przez pierwsze lata wyznaczała strategiczny kierunek rosyjskiej polityki zagranicznej.

Ta prozachodnia orientacja społeczeństwa rosyjskiego została jednak szybko podważona i nastąpił odwrót do tradycji, przypisywania znaczenia własnej wyjątkowości i odrębności, do odradzania się antyzachodniej ideologii, kształtowania postaw nacjonalistycznych, mentalności imperialnej oraz autorytarnej. Tendencja „europejska” i postrzeganie przez Rosjan

nerstwo dla Pokoju zakładającej szeroką współpracę pomiędzy NATO a Federacją Rosyjską, której zwieńczeniem mogłoby stać się włączenie Rosji do euroatlantyckiego systemu bezpieczeństwa i powstanie trwałego sojuszu amerykańsko-rosyjskiego.

11 N. M. Sirota, Osnowy geopolitiki, Sankt-Petersburg 2001, s. 102.

12 Federacja Rosyjska 1991-2001, pod red. J. Adamowskiego, A. Skrzypka, Warszawa 2002, s. 266. 
swojego państwa jako części świata europejskiego została podważona początkowo wraz z klęską polityki Michaiła Gorbaczowa i rozpadem ZSRR, następnie na skutek porażki liberalnych reform gospodarczych i politycznych w okresie rządów pierwszego prezydenta Federacji Rosyjskiej Borysa Jelcyna, a ostatecznie w wyniku niepowodzeń proeuropejskiej rosyjskiej polityki zagranicznej, która nie potrafiła zapewnić realizacji rosyjskich oczekiwań ${ }^{13}$.

Dla rosyjskiej aktywności w środowisku międzynarodowym decydujące znacznie miał proces, który można określić jako „wyparcie Rosji z Europy”. Rozpad ZSRR spowodował cofnięcie się granic państwa do linii ukształtowanej w XVII w. ${ }^{14}$ Rosyjskie elity polityczne podejmując decyzję o rozwiązaniu ZSRR miały nadzieję na zbudowanie partnerskich i równoprawnych stosunków z Zachodem, poszanowania rosyjskiej sfery wpływów, a tym samym utrzymania rosyjskiej dominacji na obszarze postradzieckim i pokojowego przejścia od ZSRR do WNP. Stosunek wysoko rozwiniętych krajów Zachodu wobec Federacji Rosyjskiej był jednak daleki od rosyjskich oczekiwań. Utrzymanie przez rozwinięte państwa Zachodu partnerskich stosunków z Rosją wynikało raczej z obawy przed możliwością destabilizacji politycznej w kraju dysponującym znacznym potencjałem militarnym niż były rzeczywistym uznaniem wartości i potencjału kraju. Rosja nie otrzymała wydatnej pomocy ekonomicznej, ani też nie została włączona do zachodnich struktur politycznych, gospodarczych i wojskowych. Rosja znalazła się w głębokim kryzysie cywilizacyjnym, który dotknął wszystkich sfer życia społecznego w tym kraju, nastąpiła także utrata jej dotychczasowej pozycji światowej, która nie została w żaden inny sposób zrekompensowana, np. poprzez widoczne podniesienie poziomu życia obywateli.

Polityka Zachodu wobec Federacji Rosyjskiej spowodowała, że Zachód zaczęto coraz powszechniej oskarżać o świadome rozbicie i dalsze osłabianie Rosji w celu wyparcia jej ze strategicznych regionów, które dotychczas były pod jej kontrolą, takich jak: Kaukaz, Azja Środkowa, Może Kaspijskie czy też Europa Środkowo-Wschodnia. Szczególne znacznie dla redefinicji rosyjskiego stosunku wobec ,partnerstwa z Zachodem” miały takie elementy, jak: ekspansja NATO na wschód, konflikt w Bośni i stosunek wobec Serbów, a także wzrost aktywności USA i UE w regionie

13 Por. A. G. Arbatov, Russia's foreign policy alternatives, „International Security" 1993, vol. 18, nr 2, s. 14-24.

14 Por. A. Kozłowski, Rosja wyparta z Europy, Toruń 2000, s. 243-250. 
Kaukazu i basenów Morza Czarnego i Kaspijskiego ${ }^{15}$. Antyzachodnia retoryka znalazła w Rosji podatny grunt przede wszystkim dlatego, iż Rosja na przełomie XX i XXI w. znalazła się w sytuacji, kiedy musiała na nowo zdefiniować swoją tożsamości cywilizacyjno-kulturową i wewnątrz rosyjskich elit politycznych trwał spór dotyczący drogi rozwoju, który powszechnie porównywano do podobnych dziewiętnastowiecznych sporów okcydentalistów ze słowianofilami. Jak pisał jeden ze współczesnych badaczy rzeczywistości rosyjskiej James Billington w rzeczywistości odrodzonej, niepodległej państwowości naród rosyjski poszukiwał swojej tożsamości ${ }^{16}$. Rosja stanęła w obliczu wyboru pomiędzy dotychczasową wielkomocarstwową tradycją, a nowoczesną tradycją liberalno-demokratyczna. W początkowym okresie zdecydowanie dominowali neookcydentaliści, ale bardzo szybko w siłę urosła autorytarno-tradycjonalistyczna alternatywa pod szyldem neoeurazjtyzmu. Lata dziewięćdziesiąte stanowią kluczowy okres dla kształtowania się nowej rosyjskiej tożsamości. Pomimo głosów płynących z Rosji zwracających uwagę, iż rosyjscy prozachodni reformatorzy potrzebują wsparcia zewnętrznego dla legitymizacji swoich działań, zarówno USA, jak i państwa Europy Zachodniej prowadziły politykę całkowicie „głuchą” na rosyjskie obawy i aspiracje. Efektem tego stała się całkowita klęska obozu prozachodnich reformatorów i powrót do etatystycznych koncepcji budowy państwa i programy reintegracji obszaru WNP z rosyjską dominacją na nim.

Reakcją rosyjską na stosunek USA i krajów UE wobec Federacji Rosyjskiej była próba redefinicji strategicznych interesów państwa i zmiana polityki zewnętrznej. Symbolem odejścia Rosji od polityki partnerstwa z Zachodem stało się objęcie w 1996 r. stanowiska ministra spraw zagranicznych przez Jewgienija Primakowa, który zastapił dotychczasowego, prozachodniego polityka, jakim był Andrzej Kozyriew. Primakow dokonał wyraźnego przewartościowania strategicznych celów polityki zagranicznej Federacji Rosyjskiej. W swoich wypowiedziach zaczął on akcentować, iż dla interesów rosyjskich w świecie taką samą wagę ma rozwój stosunków z Zachodem, jak i z Chinami, Indiami, państwami Bliskiego Wschodu, czy Ameryki Łacińskiej ${ }^{17}$.

15 Por. P. Kubicek, Russian foreign policy and the West, „Political Science Quarterly" 1999-2000, vol. 114, nr 4, s. 550-556, 561-567; A. C. Lynch, The realism of Russia 's foreign policy, „Europe-Asia Studies” 2001, vol. 53, nr 1, s. 1221.

16 Por. J. H. Billington, Russia in search of itself, Washington 2004, s. 47-51.

17 A. C. Lynch, The realism of Russia's foreign policy, s. 9-12; A. C. Lynch, The evolution of Russian foreign policy in the 1990s, ,Journal of Communist Studies 
Odpowiedzią Rosji na politykę państw Zachodnich stało się poszukiwanie innych partnerów w środowisku międzynarodowym. Już w 1998 r. Primakow podczas wizyty w Indiach apelował o stworzenie ,strategicznego trójkąta" Rosja - Chiny - Indie, który mógłby stać się podstawą dla szerokiej współpracy, która mogłaby zachwiać dominacją USA w świecie. Ta swoista „doktryna Primakowa” miała stać się geopolityczną receptą na niekorzystne dla Rosji zmiany w środowisku międzynarodowym i nieudane próby nawiązania równorzędnego partnerstwa z krajami Zachodu $^{18}$. Pod koniec lat dziewięćdziesiątych aktywność międzynarodowa Rosji została skoncentrowana na budowie strategicznych sojuszy z wschodzącymi azjatyckimi potęgami, a w XXI w. Federacja Rosyjska weszła podpisując porozumienia o strategicznym partnerstwie z Chinami (rosyjsko-chiński układ o współpracy został ostatecznie podpisany 16 lipca 2001 r.) oraz Indiami (podczas wizyty prezydenta Władimira Putina w Indiach w październiku 2000 r. została podpisana deklaracja o strategicznym partnerstwie między obydwoma krajami będąca uzupełnieniem zawartej 28 stycznie 1993 r. umowy o przyjaźni i współpracy).

Aktywności rosyjskiej na arenie międzynarodowej zaczęła sprzyjać także koniunktura $\mathrm{w}$ środowisku międzynarodowym. Zamachy terrorystyczne w Nowym Jorku we wrześniu 2001 r. spowodowały, iż Rosja stała się dla Zachodu niezwykle ważnym sojusznikiem w walce z fundamentalizmem islamskim. Prowadzenie przez Stany Zjednoczone i ich europejskich sojuszników operacji wojskowych w Afganistanie byłoby niemożliwe bez zgody i poparcia Rosji, która zachowała swoje wpływy w Rejonie Azji Środkowej. Rosja zdecydowana była wykorzystać koniunkturę jaką przyniosły jej wydarzenia z 2001. r. Jej celem zasadniczym było ukształtowanie takich stosunków z Zachodem, które pozwoliłyby na współdecydowanie w sprawach bezpieczeństwa międzynarodowego i regulacji pojawiających się kryzysów. Włączenie się do koalicji antyterrorystycznej taką możliwość Rosji stworzyło.

Dodatkowym elementem wzmacniającym pozycję Rosji w świecie stała się koniunktura gospodarcza wynikająca ze wzrostu cen ropy na światowych rynkach. Po załamaniu gospodarczym, jakie nastąpiło po rozpadzie ZSRR w latach 1999-2004 nastąpiło w Rosji wyraźne ożywienie

\& Transition Politics" 2002, vol. 18, nr 1, s. 167-169; M. Raś, Ewolucja polityki zagranicznej Rosji wobec Stanów Zjednoczonych i Europy Zachodniej w latach 1991-2001, Warszawa 2005, s. 56.

18 T. Ambrosio, The third side? The multipolar strategic triangle and the Sino - Indian rapprochement, „Comparative Strategy” 2005, nr 24, s. 399-400. 
gospodarcze i dynamiczny rozwój wszystkich sektorów gospodarki. Uznaje się, iż bardzo dobre wskaźniki ekonomiczne w tym okresie Rosja zawdzięcza przede wszystkim wysokim cenom surowców energetycznych, będących podstawą rosyjskiego eksportu. Napływ petrodolarów zapewnił doskonałą sytuację finansów publicznych, a dzięki niej stabilność wewnętrznej sytuacji społeczno-politycznej ${ }^{19}$. Dobra kondycja gospodarcza i wzrost znaczenia surowców energetycznych w świecie związany z konfliktami wokół wojny w Iraku i programu atomowego Iranu postawił Rosję w roli stabilnego eksportera tychże surowców, co przyczyniło się do podniesienia autorytetu międzynarodowego kraju i umożliwiło prowadzenie polityki zagranicznej ukierunkowanej na odzyskanie utraconych w latach kryzysu pozycji w świecie.

Zmiany zachodzące w środowisku międzynarodowym spowodowały, iż Federacja Rosyjska stała się pożądanym partnerem międzynarodowym czyniąc z niej ,języczek u wagi” w przestrzeni międzynarodowej. Jednocześnie Rosja dokonała wyboru strategicznych sojuszy na najbliższą przyszłość. Polityka „wypierania Rosji z Europy” spowodowała jednak, iż partnerem Federacji Rosyjskiej stały się nie kraje zachodnioeuropejskie oraz USA, ale wschodzące azjatyckie potęgi: Chiny oraz Indie. Zacieśnienie współpracy pomiędzy trzema wielkimi eurazjatyckimi potęgami, zbliżenie stanowisk wobec problemów budowy nowego porządku światowego, uzgodnienie wspólnych interesów, powoduje, iż powstanie „strategicznego trójkąta" Moskwa - Pekin - New Dehli może stać się ważnym elementem kształtowania się nowego ładu nie tylko w regionie Azji ale, z uwagi na rosnące znaczenie tych krajów, może także stać się znaczącym elementem przekształcenia porządku światowego, a w tym utraty przez USA pozycji światowego hegemona. Jest to tym bardziej prawdopodobne, iż kraje te nie kryją swoich aspiracji do bycia światowymi potęgami (w przypadku Federacji Rosyjskiej jest to chęć odtworzenia swojego statusu w świecie) i dążenia do realizacji wizji świata wielopolarnego ${ }^{20}$. Wskazuje się nawet, iż głównym motywem łączącym te państwa jest przede wszystkim niechęć wobec dominacji USA w świecie i narzucania całemu światu wzorów i rozwiązań amerykańsko-europejskich ${ }^{21}$.

19 Gospodarka rosyjska pod rzqdami Putina, Prace OSW, nr 20, sierpień 2005, s. 7, www.osw.waw.pl.

20 T. Ambrosio, op. cit., s. 405-408.

21 J. Rahm, Russia, China, India: A new strategic triangle for new cold war, „Parameters: US Army World College" 2001/2002, vol. 31, nr 4, s. 87. 
Zarówno Rosja, jak i Chiny oraz Indie chcą odgrywać bardziej samodzielną rolę w światowej gospodarce i polityce, są wspólnie zainteresowane w ukształtowaniu bardziej zrównoważonego, wielopolarnego, policentrycznego porządku światowego, w którym mogłyby odgrywać rolę światowych mocarstw decydujących o rozwiązywaniu problemów globalnych. Wszystkie trzy kraje mają zakodowane w swoich wzorach kulturowych przekonanie o własnej wyjątkowości (powoduje to skłonność do analizy przez pryzmat własnej kultury, tradycji i historii), postrzegają się jako kraje i społeczeństwa, które stworzyły wielkie cywilizacje o bogatych tradycjach kulturowych i politycznych, i kraje których roli współcześnie się niedocenia. Posiadają podobny stosunek wobec ukształtowanego po zimnej wojnie porządku międzynarodowego zdominowanego przez Stany $Z_{\text {Jjednoczone }}^{22}$. Zbliżony jest także ich stosunek i ocena procesów globalizacji. Dominują oceny pragmatyczne i postrzeganie tychże procesów jako szansy na rozwój i stymulację wzrostu gospodarczego. Jednocześnie jednak wyrażają swój sprzeciw wobec narzucania logiki globalizacji przez rozwinięte kraje zachodnioeuropejskie, które za pośrednictwem globalizacji rozszerzają swoje strefy wpływów politycznych i gospodarczych oraz narzucają własne standardy, wartości i rozwiązania pozostałym regionom świata. Opowiadają się za globalizacją, której efekty zostały by sprawiedliwiej rozdzielone w środowisku międzynarodowym. Wspólna jest definicja negatywnych aspektów globalizacji i wola wspólnego przeciwstawienia się im, a środkiem dla obrony własnych interesów miały by stać się pogłębiona współpraca gospodarcza i polityczna ${ }^{23}$. Dlatego też proces trilateralnej współpracy wspiera się na wspólnocie interesów i podobnym postrzeganiu rzeczywistości międzynarodowej.

Powstanie strategicznego trójkąta Rosja - Chiny - Indie zostało odebrane z zaniepokojeniem przez zachodnich analityków. Zwrócono baczniejszą uwagę na rolę Federacji Rosyjskiej w świecie i jej znaczenie jako sojusznika Zachodu. Zdecydowane dystansowanie się Rosji od współpra-

22 Por. J. Zajączkowski, Indyjska wizja porzqdku międzynarodowego, w: Porzadek międzynarodowy u progu XXI wieku, pod red. R. Kuźniara, Warszawa 2005, s. 313-334; A. Kołodziejczyk, Chińskie wizje rzeczywistości międzynarodowej, w: Porzqdek..., s. 335-356; M. Menkiszak, Rosyjskie wizje pozimnowojennego porzqdku międzynarodowego, w: Porzqdek..., s. 275-296.

M. Titarenko, Russia, China and India in a globalized world, „International Affairs: A Russian Journal of World Politics, Diplomacy \& International Relations" 2002, vol 48, nr 4, s. 61-64. 
cy z USA wzbudziło szczególne obawy w Ameryce. USA wciąż zagrożone możliwością ataków terrorystycznych na własnym terytorium, uwikłane w wojnę w Iraku, angażujące siły zbrojne w coraz bardziej niestabilnym Afganistanie potrzebują w środowisku międzynarodowym nowych sojuszników, którzy wzmocniliby ich pozycję, a nie nowych rywali i wrogów ${ }^{24}$. Tymczasem stosunki między Moskwą a Waszyngtonem uległy gwałtownemu pogorszeniu. Chybiona i arogancka polityka USA wobec Federacji Rosyjskiej prowadzona w latach dziewięćdziesiątych zaczęła skutkować coraz większym dystansowaniem się Federacji Rosyjskiej od Zachodu, poszukiwaniem nowych sojuszników w środowisku międzynarodowym, odrodzeniem się w Rosji antyzachodniej demagogii i coraz bardziej asertywną polityką wobec USA i UE, co spotyka się ze społeczną aprobatą. Niezależnie od wielu okazji, do poprawy stosunków dwustronnych i nawiązania partnerskich kontaktów dyplomacja amerykańska traktowała Federację Rosyjską jako „pokonanego wroga” i nie przywiązywała wagi do nawiązywania specjalnych kontaktów z Rosją ${ }^{25}$.

Niechętne, a nawet wrogie reakcje obecnych władz Federacji Rosyjskiej wobec USA i UE wywołane zostały egoistyczną polityką Zachodu wobec Federacji Rosyjskiej i postępującym procesem „wypierania Rosji z Europy" oznaczającym nie tylko cofnięcie jej granic do linii z XVII w., ale przede wszystkim odrzuceniem rosyjskich ambicji stania się ważnym elementem wspólnoty europejskiej oraz szanowanym sojusznikiem USA. Polityka Zachodu wobec Federacji Rosyjskiej i odrzucenie jej aspiracji była wynikiem przekonania o słabości Rosji i braku jej możliwości skutecznego przeciwstawienia się dominacji w świecie USA $\mathrm{i}$ jej europejskich sojuszników, a tym samym wywoływało przekonanie o braku konieczności liczenia się z rosyjskimi aspiracjami. Postępująca odbudowa międzynarodowej pozycji Federacji Rosyjskiej, nawiązanie strategicznego partnerstwa z Chinami oraz Indiami, zmieniła jednak stosunek wobec Rosji i zaczęto coraz częściej dostrzegać polityczne błędy popełnione wobec niej.

W obecnej sytuacji międzynarodowej (rosnące zagrożenie międzynarodowym terroryzmem, destabilizacja Iranu oraz Afganistanu, gwałtownie rosnące ceny ropy, trudności gospodarcze w USA) spowodowały, iż coraz częściej zaczęto dostrzegać niebezpieczeństwo „utraty Rosji”, jako

24 D. K. Simes, Losing Russia, „Foreign Affairs” 2007, vol. 86, nr 6, s. 36.

25 Ibidem, s. 37-38. 
partnera dla Zachodu łagodzone jednakże przekonaniem, iż Zachód i Federacja Rosyjska są dla siebie naturalnymi partnerami i obie strony są sobie potrzebne oraz przekonanie, iż mimo wszelkich kontrowersji Rosja pozostanie dla Zachodu bardziej „partnerem” niż „rywalem”26.

Wydaje się jednak, iż są to oceny zbyt optymistyczne, gdyż postępująca odbudowa gospodarki rosyjskiej, a także wzrost jej znaczenia międzynarodowego powodują, iż rosyjskie władze świadomie dążą do odbudowy swojej sfery wpływów i nie kryją swoich aspiracji zaznaczając, iż ingerencja w „sferę żywotnych interesów rosyjskich” będzie oznaczała podjęcie przez Federację Rosyjską odpowiednich kroków. Przywrócenie dobrych stosunków z Federacją Rosyjską będzie niezwykle trudne przede wszystkim z uwagi na głębokie rozczarowanie Rosjan polityką Zachodu wobec ich kraju, a także z uwagi na fakt, iż pojawiają się nowe pola konfliktów, które mogą doprowadzić wyłącznie do dalszego dystansowania się Rosji od Zachodu. Najbliższym polem konfliktów najprawdopodobniej staną się Gruzja i Ukraina ${ }^{27}$. Bardzo prawdopodobne włącznie tych państw w sferę wpływów europejsko-amerykańskich poprzez rozszerzenie NATO będzie oznaczało, iż możliwości współpracy z Federacją Rosyjską spadną do minimum, gdyż elity i społeczeństwo rosyjskie nie pogodzą się z dalszym ograniczaniem roli Rosji na strategicznym obszarze WNP, uznanym przez Rosjan za sferę, ich żywotnych interesów. Federacja Rosyjska będąc krajem, który w przeszłości odgrywał wiodącą rolę w świecie nie pogodzi się z sytuacją zepchnięcia jej na margines międzynarodowej sceny politycznej i roli aktora „drugiego rzędu". Oznaczać to będzie zdecydowaną reakcję rosyjską i dążenie do dalszego zacieśniania kontaktów z Chinami, Indiami czy też z Iranem, co skutkować może coraz silniejszą rywalizacją międzynarodową i eskalacją konfliktów.

Konsekwencją procesów „wyparcia Rosji z Europy” stało się więc utworzenie strategicznego trójkąta Moskwa - Pekin - New Dehli oraz upadek nadziei na prognozowany przez Francisa Fukuyame „koniec historii” i zdominowanie świata przez zachodnioeuropejskie wartości liberalno-demokratyczne. Wyraźne zdystansowanie się Rosji od wspólnoty krajów Zachodu podkreślanie znaczenia własnych tradycji, odbieranie

26 S. Bieleń, op. cit., s. 355.

27 Zob. A. Modrzejewski, Cywilizacyjno-kulturowy kontekst ,,pomarańczowej rewolucji” "na Ukrainie, ,Środkowoeuropejskie Studia Polityczne” 2005, nr 2, s. 21-37. 
prób skłonienia Rosji do uznania wartości zachodnioeuropejskich, jako „imperializmu kulturowego" spowodowało, iż świat Zachodu stracił ważnego sojusznika, który ze względu na swoje eurazjatyckie położenie zawsze odgrywał rolę państwa, które przenosiło europejskie tradycje i wartości na kolonizowane przez siebie tereny Azji. Rosja w swoim postrzeganiu świata zewnętrznego przeszła trudną drogę od gorbaczowowskiej idei „Europy - wspólnego domu” do tworzenia „wspólnej azjatyckiej przestrzeni" z Chinami oraz Indiami podczas drugiej kadencji Władimira Putina. Tym samym na progu XXI w. została zaprzepaszczona okazja na demokratyzację Rosji (a zarazem całej przestrzeni eurazjatyckiej), przekształcenia jej w kraj nowoczesny i odwołujący się do wartości demokratycznych i liberalnych wyrastających z europejskiego pnia cywilizacyjnego.

Antyokcydentalistyczny zwrot w polityce rosyjskiej nie musi być zjawiskiem trwałym, ponieważ Rosjanie wciąż mają silne poczucie przynależności do kultury i cywilizacji europejskiej, ale „odzyskanie” Federacji Rosyjskiej jako partnera Zachodu będzie trudne i dużo kosztowniejsze niż miałoby to miejsce na początku lat dziewięćdziesiątych, kiedy to Rosja była gotowa do znaczących ustępstw, do poddania się procesom modernizacji i demokratyzacji za cenę włączenia jej do „wspólnego europejskiego domu". Obecne procesy zachodzące w środowisku międzynarodowym powodują, iż gorbaczowowska wizja, która stała się podstawą dla prozachodniego zwrotu w polityce Rosji, nigdy chyba nie była dalsza od swojego urzeczywistnienia. Jednocześnie jednak polityczne deklaracje obecnych prezydentów USA i Rosji Barcka Obamy i Dmitija Miedwiediewa o „nowym otwarciu" w dwustronnych stosunkach mogą świadczyć o próbie odejścia od polityki konfrontacji na rzecz budowy wzajemnych stosunków opartych na współpracy. Rezygnacja administracji USA z forsowania koncepcji tarczy rakietowej w Europie Środkowo-Wschodniej oraz rosyjskie deklaracje dotyczące zgody na sankcje wobec Iranu stanowią rzeczywisty przełom w relacjach Federacja Rosyjska-USA. Pojawia się jednak pytanie, czy nie jest to polityka spóźniona o dwie dekady i czy zdominowanie amerykańskiej polityki zagranicznej w latach dziewięćdziesiątych przez ,jastrzębi” i realistów politycznych, którzy traktowali Rosję tak jak gdyby nie zakończyła się jeszcze zimna wojna, nie przyniosło trwałych szkód we wzajemnych stosunkach Rosja-Zachód, a pokłady wzajemnej niechęci i braku zaufania nie są już zbyt duże aby przywrócić gorbaczowowską wizję Europy „od Atlantyku do Uralu” i fukyamowski optymizm dotyczący „końca historii”. 


\section{Summary}

The anti-Occidental turn of Russian policy does not have to be permanent as the Russians still have a strong feeling of belonging toEuropean culture and civilization; yet winning the Russian Federation's 'backing' as a partner of the West will be difficult and significantly more costly than it would have been in the early 1990s, when Russia was ready to make considerable concessions, to undergo the process of modernization and democratization in return for being included in the 'common European home.' The consequence of current processes in the international environment is that Gorbatchev's vision, which became the foundation for the pro-Western turn in Russian policy, has never been further away from its implementation. 